\title{
Estimation of passive immunity in newborn calves with routine clinical chemistry measurements
}

\author{
Mert PEKCAN ${ }^{1}$, Ulvi Reha FIDANCI ${ }^{1}$, Banu YUCEER ${ }^{2}$, Ceyhan OZBEYAZ ${ }^{2}$ \\ ${ }^{1}$ Ankara University, Faculty of Veterinary Medicine, Department of Biochemistry; ${ }^{2}$ Ankara University, Faculty of Veterinary \\ Medicine, Department of Animal Husbandry, Ankara, Turkey.
}

Summary: The minimisation of neonatal mortality is critical for the success of an animal management programme. The period between calving and weaning is the most crucial period in the animal's life. A major management tool that could be used to reduce health problems in calves is feeding with colostrum. Colostrum is rich in energy, protein and vitamins (especially vitamins A, $\mathrm{D}, \mathrm{E}$ and B12). Most importantly, colostrum is essential for newborns, in that it contains high levels of immunoglobulins, which transfer passive immunity to the calf, and thereby, enable it to fight with infections. The aim of the present study was to determine the correlation between serum Ig G levels and routine biochemical parameters in neonatal Holstein calves given colostrum with teat buckets separated soon after calving. For this purpose, serum was extracted from blood samples collected from 79 calves within 24-48 hours of calving. The passive transfer status of the calves was determined by measuring the Ig G content of serum by ELISA. Based on their serum Ig G levels, the calves were divided into 3 groups (insufficient $n=13$; partial $n=14$; and normal passive transfer $n=52$ ). Serum ALT, AST, GGT, ALP, LDH activities and serum BUN, creatinine, albumin, total protein, total bilirubin, triglyceride, cholesterol, and glucose levels were analysed. A statistically significant increase was determined in the serum GGT activity and total protein and urea levels of calves with normal passive immunity transfer by colostrum, compared to the other passive transfer groups $(\mathrm{p}<0.05)$. Even though slight differences were observed between groups regarding the remaining biochemical parameters, there is no significant differences were observed between the passive transfer groups for the other assayed parameters $(\mathrm{p}>0.05)$. In conclusion, these results showed that total protein and BUN levels in combination with the serum-GGT activity as a reliable criterion for the determination of passive transfer status can be used in newborn calves.

Key words: Calf, clinical biochemistry, colostrum, passive transfer.

\section{Yenidoğan buzağıların pasif bağışıklık düzeylerinin rutin biyokimyasal yöntemler ile tahmini}

Özet: Yavru ölümlerinin en aza indirilmesi, hayvancılıkta başarının önemli unsurlarından birisini oluşturur. Buzağılama ve sütten kesme aşaması arasında geçen süre hayvanın yaşamında kritik bir süreçtir. Buzağılarda sağlık sorunlarının azaltılması yönünde kullanılan önemli bir araç da kolostrumla beslemedir. Kolostrumun enerji, protein ve vitamin (özellikle A, D, E ve B12) içeriği yüksektir. Daha da önemlisi kolostrum enfeksiyonlar ile savaşmak için gerekli pasif bağışıklık öğelerinden immunglobulinlerin buzağılara aktarılması yönü ile vazgeçilmezdir. Bu çalışma, doğum sonrası kulübelere alınmış ve emzikli kovalar aracılığı ile kolostrum almış yenidoğan Holştayn buzağılarda Ig G düzeyleri ile rutin klinik biyokimya parametreleri arasındaki ilişkinin incelenmesi amacıyla yapılmıştır. Bu amaçla 79 baş buzağından doğumu izleyen 24-48 saat içerisinde kan örnekleri alınarak serumları çıkartılmıştır. Buzağıların pasif transfer düzeylerinin gösterilmesi için Ig G düzeyleri ELISA ile belirlenmiştir. Ig G düzeylerine göre buzağılar üç gruba ayrılmıştır (yetersiz $n=13$, kısmi n=14, ve normal pasif transfer $n=52$ ). Serum örneklerinde ALT, AST, GGT, ALP, LDH aktiviteleri ve BUN, kreatinin, albumin, toplam protein, toplam bilirubin, trigliserid, kolesterol ve glikoz düzeyleri ölçülmüştür. Kolostrum ile normal pasif transfer sağlayan buzağılarda serum GGT aktivitesi, toplam protein ve üre düzeyleri diğer pasif transfer gruplarına göre artış göstermiş ve artış istatistik yönden önemli bulunmuştur ( $\mathrm{p} \leq 0.05)$. İncelenen diğer parametrelere ilişkin sonuçlarda pasif transfer grupları arasında istatistik olarak önemli farklılıklar gözlenmemiştir ( $p \geq 0.05$ ). Sonuç olarak serum GGT düzeyinin buzağılarda pasif transfer durumunu belirlemede iyi bir kriter olabileceği, fakat toplam protein ve üre düzeylerinin tek başına olmasa da GGT düzeyi ile birlikte değerlendirilmeye alındığı taktirde faydalı olabileceği kanısına varılmıştır.

Anahtar sözcükler: Buzağı, klinik biyokimya, kolostrum, pasif transfer

\section{Introduction}

The minimisation of neonatal mortality is critical for the success of an animal management programme. When born, ruminants do not have any immunoglobulins circulating in their bloodstream. For this reason, the period between calving and weaning is a very critical stage in the animal's life (8). Colostrum feeding is an important tool used to reduce health problems that may be observed in calves. Colostrum feeding is essential for calves, not only because colostrum is rich in energy, proteins and vitamins (in particular vitamins A, D, E and $\mathrm{B} 12)$, but also due to colostrum containing proteins and 
peptides, which have strong biological activity, as well as immunoglobulins, which are an important component of passive immunity and are transferred to calves by the feeding of maternal colostrum $(8,11)$. The major classes of immunoglobulins found in bovine serum and lacteal secretion are IgG, IgM and IgA. These immunoglobulins are selectively transported from the serum into the mammary gland, resulting in highly concentration of immunoglobulins in the colostrum. The main fractions of immunoglobulins are IgG1 which accounts for $75 \%$ in colostral whey, followed by IgM, IgA and IgG2 (10).

The determination of colostrum immunoglobulin levels bears significance, in that it aids in determining the quality of colostrum, and because it is important for the reduction of the risk of disease in newborn animals (20). Although immunoglobulin levels can be determined accurately by single radial immunodiffusion (SRID) and enzyme-linked immunosorbent assay (ELISA), these methods are both costly and time consuming (2). On the other hand, although easily applicable and inexpensive, the zinc sulphate and sodium sulphate turbidity tests do not produce sensitive results. In this respect, the development and use of inexpensive, highly sensitive, rapid tests that can be easily applied under field conditions would provide major advantages $(2,11)$.

In calves and lambs, intestinal absorption being non-selective within the first 24-48 hours of life, enables the direct absorption of several proteins and macromolecular substances from the intestines (16). If the newborn animal is fed with maternal colostrum within this time period, apart from immunoglobulins, several colostral enzymes may also be absorbed from the intestines (2). The measurement of serum enzyme levels in goats and some other ruminants, aids in the determination of the immunity level in these animals (20).

The present study was aimed at the assessment of the feasibility of the prediction of serum immunoglobulin levels in newborn calves by means of the measurement of routine biochemical parameters. Thereby, it would be possible to monitor the passive transfer status of newborn animals more easily and rapidly, at much lower costs, alternatively to methods such as ELISA, which are both difficult to apply under field conditions and expensive.

\section{Materials and Method}

Blood samples were collected within the first 24-48 hours of calving from 79 calves raised at the Bala Agricultural Enterprise subordinated to the General Directorate for Agricultural Enterprises (TIGEM) of the Ministry of Agriculture and Rural Affairs. All the animals included in the study were given birth from the cows which were raised in similar conditions. Soon after calving they were separated and given colostrum with teat buckets. Serum was extracted from the blood samples of these animals to determine the passive transfer status of the calves using a commercial Bovine Ig G ELISA kit (Alpha Diagnostic International). Based on their serum Ig G levels, the calves were allocated to three groups (insufficient $\mathrm{n}=13 ;<800 \mathrm{~m} \mathrm{~g} / \mathrm{dl}$, partial $\mathrm{n}=14 ; 800-1600 \mathrm{mg} / \mathrm{dl}$ and normal passive transfer $\mathrm{n}=52$; $>1600 \mathrm{mg} / \mathrm{dl}$ ) (18). Using an Abbot Alcyon 300 autoanalyser and commercial kits, ALT (alanine amino transferase), AST (aspartate amino transferase), GGT (gamma glutamyl transpeptidase), ALP (alkaline phosphatase), LDH (lactate dehydrogenase) activities and BUN, creatinine, albumin, total protein, total bilirubin, triglyceride, cholesterol, and glucose levels were measured.

The compliance of the measurements with the normal distribution was assessed by the KolmogorovSmirnov test. As the values were confirmed to show a normal distribution, one-way analysis of variance (ANOVA) was performed. Differences between the trial groups were determined by means of Duncan's test (5).

\section{Results}

The results obtained in the present study demonstrated that (Table 1), in calves, in which normal passive immunity transfer had occurred through colostrum feeding, serum GGT activity, total protein and BUN levels had increased significantly in comparison to the other passive transfer groups $(\mathrm{p} \leq 0.05)$. Even an increase in AST activity and cholesterol levels were observed no statistically significant difference between the passive transfer groups for any of the remaining routine biochemical parameters assayed ( $\mathrm{p} \geq 0.05$ ). Even though BUN levels was found to be within reference ranges, total protein values were lower in the insufficient transfer group and GGT levels were remarkably higher in the normal passive transfer group.

\section{Discussion and Conclusion}

Passive immunity acquired by the fetus via the placenta and/or colostrum after birth is crucial for adaptation of the neonate to the extrauterine environment. The maternal antibodies transferred to the newborn either by placenta and or colostrum aiding them to combat against infections in the very early stages of their life (4).

Ruminants are born with a rather weak immunity system. The main mechanism of protection at the beginning of their lives is the maternal immunoglobulins transferred by colostrum feeding (13). The structure of their placenta is the reason for their being devoid of immunoglobulins at birth (1).

As explained for the ruminants whose their placenta acts as a barrier for the transfer of antibodies to the fetus during gestation, the only possible route to transfer passive immunity is the ingestion and absorption of 
Table 1: The means $(\mathrm{x} \pm \mathrm{Sx})$ of some of the routine biochemical parameters measured for the three different groups. Tablo 1. Ölçümü yapılan bazı rutin biyokimysal parametrelerin gruplara göre ortalama değerleri.

\begin{tabular}{llllc}
\hline & \multicolumn{1}{c}{ Insufficient Passive Transfer } & \multicolumn{2}{c}{ Partial Passive Transfer } & \multicolumn{2}{c}{ Normal Passive Transfer } \\
& \multicolumn{1}{c}{$\mathrm{n}=13$} & \multicolumn{1}{c}{$\mathrm{n}=14$} & Sig. \\
\hline ALT (IU/L) & $10.85 \pm 1.67 \mathrm{a}$ & $11.93 \pm 2.15 \mathrm{a}$ & $11.33 \pm 0.87 \mathrm{a}$ & $\mathrm{p} \geq 0.05$ \\
AST (IU/L) & $52.23 \pm 6.46 \mathrm{a}$ & $51.79 \pm 2.28 \mathrm{a}$ & $60.35 \pm 2.72 \mathrm{a}$ & $\mathrm{p} \geq 0.05$ \\
GGT $(\mathrm{IU} / \mathrm{L})$ & $252.62 \pm 53.36 \mathrm{a}$ & $416.64 \pm 79.37 \mathrm{ab}$ & $578.25 \pm 47.45 \mathrm{~b}$ & $\mathrm{P} \leq 0.05$ \\
BUN $(\mathrm{mg} / \mathrm{dl})$ & $6.92 \pm 0.94 \mathrm{ab}$ & $5.43 \pm 0.46 \mathrm{a}$ & $9.28 \pm 0.82 \mathrm{~b}$ & $\mathrm{P} \leq 0.05$ \\
Albumin $(\mathrm{g} / \mathrm{dl})$ & $2.76 \pm 0.09 \mathrm{a}$ & $2.58 \pm 0.05 \mathrm{a}$ & $2.77 \pm 0.05 \mathrm{a}$ & $\mathrm{p} \geq 0.05$ \\
Cholesterol $(\mathrm{mg} / \mathrm{dl})$ & $29.62 \pm 2.90 \mathrm{a}$ & $30.79 \pm 2.37 \mathrm{a}$ & $33.23 \pm 1.57 \mathrm{a}$ & $\mathrm{p} \geq 0.05$ \\
LDH $(\mathrm{IU} / \mathrm{L})$ & $534.00 \pm 43.60 \mathrm{a}$ & $510.00 \pm 43.46 \mathrm{a}$ & $512.00 \pm 26.43 \mathrm{a}$ & $\mathrm{p} \geq 0.05$ \\
ALP $(\mathrm{IU} / \mathrm{L})$ & $499.00 \pm 55.32 \mathrm{a}$ & $390.86 \pm 25.31 \mathrm{a}$ & $459.10 \pm 18.90 \mathrm{a}$ & $\mathrm{p} \geq 0.05$ \\
T. bilirubin $(\mathrm{mg} / \mathrm{dl})$ & $0.58 \pm 0.09 \mathrm{a}$ & $0.90 \pm 0.18 \mathrm{a}$ & $0.82 \pm 0.07 \mathrm{a}$ & $\mathrm{p} \geq 0.05$ \\
T. protein $(\mathrm{g} / \mathrm{dl})$ & $4.7 \pm 0.2 \mathrm{a}$ & $5.13 \pm 0.2 \mathrm{ab}$ & $5.48 \pm 0.13 \mathrm{~b}$ & $\mathrm{P} \leq 0.05$ \\
Creatinine $(\mathrm{mg} / \mathrm{dl})$ & $1.4 \pm 0.13 \mathrm{a}$ & $1.4 \pm 0.10 \mathrm{a}$ & $1.18 \pm 0.07 \mathrm{a}$ & $\mathrm{p} \geq 0.05$ \\
Triglyceride $(\mathrm{mg} / \mathrm{dl})$ & $30.3 \pm 6.1 \mathrm{a}$ & $29.2 \pm 6.7 \mathrm{a}$ & $30.0 \pm 3.9 \mathrm{a}$ & $\mathrm{p} \geq 0.05$ \\
Glucose $(\mathrm{mg} / \mathrm{dl})$ & $122 \pm 10.9 \mathrm{a}$ & $121 \pm 6.9 \mathrm{a}$ & $119 \pm 4.42 \mathrm{a}$ & $\mathrm{p} \geq 0.05$ \\
\hline
\end{tabular}

colostrum $(3,6)$ Besides given factors above even though there are greater numbers of phagocytic cells in the neonate the function of these cells is decreased (7) which makes them highly dependent to the colostrum which plays an important role in the host defence (14).

There are various tests have been offered to evaluate passive transfer status in domestic animals. The immunological tests of which the radial immunodiffusion and the enzyme-linked immunosorbent assay (ELISA) are the main ones that directly measure serum IgG concentrations. The other tests which include sodium sulfite turbidity test, zinc sulfate turbidity test, serum refractometry, serum GGT activity, and whole-blood glutaraldehyde gelation predicts serum IgG levels based on estimation of total globulins or other proteins whose passive transfer is associated with that of $\operatorname{IgG}(16)$.

Immunoassays are not commonly used for detecting $\mathrm{IgG}$ in farm animals due to time constraints of sample collection, sample submission and assay procedures. Labor and expense also acted as a limiting factor on broad use of immunoassay procedures on-farm applications (15).

As absorption from the intestines is non-selective within the first 24-48 hours after birth, several proteins and macromolecular substances are able to be directly absorbed from the intestinal canal (2).

The enzyme GGT is produced by the cells lining the excretory ducts of the mammary glands (16). Therefore, it is considered that the enzyme GGT is absorbed from the intestines similar to immunoglobulins (2). Previous research has shown that GGT activity in the colostrum is on average 400-800 times higher than that in the serum of adult animals $(12,13)$. Based on this fact, it has been reported that in calves fed on colostrum, serum GGT activity is $60-160$ times higher than that of adult animals (13).
Similarly, it was ascertained in the present study that, in the groups with partial and normal passive transfer, GGT activity was statistically higher than that of the group with insufficient passive transfer $(\mathrm{P} \leq 0.05)$. Similar findings have also been reported by other researchers $(19,20)$. For this reason, the increase observed in the present study and similar research is considered to have arisen from colostrum feeding.

Zarilli et al. (2003), in a study conducted in goats, determined that Ig G levels were weakly correlated with serum LDH and ALP activities. On the other hand, in a study carried out by Maden et al. (2004) in lambs, it was determined that serum ALP levels proved to be inadequate in determining the passive transfer status of animals. These results are in compliance with the findings of the present study.

Increased BUN levels are generally associated with diseases of the kidneys, and if observed concurrently with increased creatinine levels, they may be interpreted as an indication of renal dysfunction (9). In the present study, creatinine levels were not observed to have increased. The independent increase of urea levels is observed as a result of either nutrition on a high protein diet or gastrointestinal haemorrhage, whilst increased total protein levels are generally associated with dehydration and increased gamma globulin levels due to infection (17).

It is known that, colostrum has high protein content, mainly composed of immunoglobulins (2). For this reason, increased urea levels were attributed to nutrition. The underlying reason of increased total protein levels was considered to be the percentile increase of the serum gammaglobulin fraction, owing to the absorption of immunoglobulins from the intestines.

The most remarkable change was observed in GGT activity. As explained above increased GGT activity not 
to be considered as a leakage protein from the tissue as observed in various disease states, but it is caused by the absorption of highly active protein which was found in the ingested milk originated from the mammary gland $(2,16)$.

In result, it was concluded that serum GGT activity may serve as a reliable criterion for the determination of passive transfer status in newborn calves, whilst total protein and urea levels, although not when assessed alone, may prove to be of use if assessed in combination with GGT activity.

\section{References}

1. Arguello A, Castro N, Zamorano MK, Castroalonso A, Capote J (2004): Passive transfer of immunity in kid goats fed refrigerated and frozen goat colostrum and commercial sheep colostrum. Small Ruminant Research, 54, 237-241.

2. Britti D, Massimmini G, Angelo P, Luciani A, Boari A (2005): Evaluation of serum enzyme activities as predictors of passive transfer status in lambs. JAVMA, 226, 951-955.

3. Crisman MV, Scarratt, WK (2008): Immunodeficiency disorders in Horses. Vet Clin North Am Equine Pract, 24, 299-310.

4. Diker KS (1998): Immunoloji. Medisan Yayınevi. Ankara.

5. Duzgunes O, Kesici T, Gurbuz F (1983): Istatistik Metodlari. Ankara Universitesi Ziraat Fakultesi Yayinlari No 861, Ankara Universitesi Basimevi, Ankara, Turkey.

6. Giguère $\mathbf{S}$, Polkes $\mathbf{A C}$ (2005). Immunologic disorders in neonal foals. Vet Clin North Am Equine Pract, 21, 241-272.

7. Hauser MA, Koob MD, Roth JA (1986): Variation of neutrophil function with age in calves. Am J Vet Res, 47, 152-3.

8. Jaster EH (2005): Evaluation of quality, quantity, and timing of colostrum feeding on immunglobulin $G_{1}$ absorbtion in Jersey calves. J Dairy Sci 88, 296-3002

9. Karagul H, Altintas A, Fidanci UR, Sel T (2000): Klinik Biyokimya. Medisan Yayinlari, Ankara, Turkey.

10. Korhonen H, Marnila P, Gill HS (2000): Milk immunoglobulins and complement factors. Br J Nutr 84, Suppl 1:S75-80.

11. Kung L, "The Importance of Colostrum for Calves" 12.12. 2009

$<$ http://ag.udel.edu/anfs/faculty/kung/articles/importance_of _colostrum_for_calv.htm>
12. Maden M, Birdane FM, Altunok V, Dere S (2004): Serum and colostrum/milk alkaline phosphatase activities in the determination of passive transfer status in healthy lambs. Revue med Vet 155, 565-569.

13. Parish SM, Tyler JW, Besser TE, Gay CC, Krytenberg D (1997): Prediction of Serum $\operatorname{Ig} G_{I}$ concentration in holstein calves using serum gamma glutamyltransferase activity. J Vet Intern Med 11, 344-347.

14. Stelwagen K, Carpenter E, Haigh B, Hodgkinson A, Wheeler TT (2008): Immune components of bovine colostrum and milk. J Anim Sci. 87(13 Suppl), 3-9.

15. Tyler JW, Hancock DD, Parish SM, Rea DE, Besser TE, Sanders SG, Wilson LK (1996): Evaluation of 3 assays for failure of passive transfer in calves. J Vet Intern Med. 10, 304-7.

16. Waver DM, Tyler JW, Vanmetre DC, Hostetler DE, Barrington GM (2000): Passive transfer of colostral immunglobulins in calves. J Vet Intern Med 14, 569-577

17. Willard MD, Tvedten H (2004): Small animal clinical diagnosis by laboratory methods. Saunders, MO, USA.

18. Wittum TE, Perino LJ (1995): Passive immune status at postpartum hour 24 and long-term health and performance of calves. Am J Vet Res, 56, 1149-1154.

19. Zanker IA, Hammon MH, Blum WJ (2001): Activities of $\gamma$-glutamyltransferase, alkaline phosphatase and aspartate-aminotransferase in colostrum, milk and blood plasma of calves fed first colostrum at 0-2, 6-7,12-13 and 24-25h after birth. J Vet Med 48, 179-185.

20. Zarilli A, Micera E, Lacarpia N, Lombardi P, Pero ME, Pelagalli A, Angelo D, Mattia M, Avallone L (2003): Evaluation of goat colostrum quality by determining enzyme activity levels. Livest Prod Sci 83, 317-320.

Geliş tarihi: 04.05.2012 / Kabul tarihi: 14.01.2013

Address of correspondence:

Ulvi Reha Fidancl

Ankara University

Faculty of Veterinary Medicine

Department of Biochemistry

06110 Ankara -Turkey

fidanci@ankara.edu.tr 